\title{
MSG Wastewater Treatment with UASB-AOMBR Coupling process
}

\author{
Yong Gao, Manying Zhang, Feng Kong \\ School of Chemistry and Environmental Engineering \\ Jiangsu University of Technology \\ Changzhou, China \\ gaoyong@jsut.edu.cn
}

\begin{abstract}
Keywords- MSG wastewater; UASB; MBR; ammonia; volatile fatty acids (VFA)
Abstract-Monosodium glutamate (MSG) wastewater is a very refractory case of high strength organic wastewater. To investigate the effect of operating variables on treatment of MSG wastewater, a laboratory scale study was conducted. The treatment of MSG wastewater was studied by UASB-A/OMBR process. The effect of operating variables such as organic volumetric load rate (OLR), $\mathrm{pH}$, volatile fatty acids (VFA), ammonia $\left(\mathrm{NH}_{3}-\mathrm{N}\right)$ and alkalinity on efficiency of treatment and recovery of biogas was investigated. The results showed that, in the UASB stage, the gas production rate was $3.02-8.83 \mathrm{~kg} \mathrm{COD} / \mathrm{m}^{3} \cdot \mathrm{d}$ volume load, the gas production rate and COD load volume was positively related; as influent COD in range of $11878-16922 \mathrm{mg}^{-1}{ }^{-1}$, COD removal rate of effluent was in range of $57.00-79.63 \%$. The removal of COD by MBR can reach $90 \%$, even to $96 \%$, and the removal of ammonia is $95 \%-100 \%$. UASB--A/O MBR has a good ability of preventing fluctuation of load and can remove COD and ammonia effectively.
\end{abstract}

\section{INTRODUCTION}

Monosodium glutamate (MSG) factories, both at medium and large scale, suffer from inadequate treatment and disposal problems due to high concentration of $\mathrm{COD}, \mathrm{Cl}^{-}, \mathrm{NH}_{3}-\mathrm{N}, \mathrm{SO}_{4}{ }^{2-}$ contents present in the wastewater ${ }^{[1,2]}$. In order to insure the sustainable development of the MSG industry, more efforts have been directed toward the acquisition of feasible, efficient and economical methods for treating MSG wastewater ${ }^{[3]}$. With the increase of MSG production, efficient treatment of MSG wastewater had been considered as an emergency problem to be solved ${ }^{[4]}$.

Many of these studies and nearly all applications have incorporated anaerobic pretreatment with aerobic biological treatment as polishing stage. Anaerobic treatment, while removing a high percentage of many contaminants, some of which are quite recalcitrant in aerobic treatment, produces effluent that is rarely suitable for direct discharge to a receiving water. Subsequently, much attention has been focused on anaerobic-aerobic treatment sequences to biologically treated wastewaters containing a wide variety of novel, often toxic, xenobiotic compounds.

The upflow anaerobic sludge blanket (UASB) has been successfully implemented for the treatment of high strength industrial effluents. Researchers have conducted many studies. The characteristics of anaerobic microbial granules grown in an UASB reactor treating catechol bearing synthetic wastewater (SWW) were studied by Revanuru Subramanyam $(2008)^{[5]}$, the specific methanogenic activity of the sludge showed an increase in trend with an increase in the organic loading rate and the catechol concentration in the SWW. The substrate composition and organic loading rate on the process performance during start-up and steady state were studied by $\mathrm{N}$. Musee (2007) ${ }^{[6]}$, Kaan Yetilmezsoy (2009) ${ }^{[7]}$ Matsumoto and Noike $(1991)^{[8]}$. The optimum values of operating variables for treating hog wastewater were reported (Chen et al., 1997) ${ }^{[9]}$ for the anaerobic fluidized bed treatment of hog wastewater. The feasibility of treatment of monosodium glutamate fermentation wastewater was evaluated (Tseng and Lin, 1990) ${ }^{[10]}$ in terms of removal efficiency and methane content in the biogas. A BOD removal efficiency of $90 \%$ was attained with a methane content of $80.8 \%$ and OLR of $10.1-31.1 \mathrm{~kg} \mathrm{COD} \mathrm{m}^{-3} \cdot$ day $^{-1}$. 
In the past three decades, the membrane bioreactor (MBR) has been paid high attention in wastewater treatment and reuse as a promising technology ${ }^{[1,12]}$. In contrast to the traditional technologies (i.e. conventional activated sludge, stabilization ponds, SBR, etc.), Replacing secondary clarifiers in the conventional activated sludge process with membrane units, MBR have better effluent quality, smaller footprint and much less waste sludge owing to its operation at relatively long sludge age and low sludge loading rate (Brindle and Stephenson, 1996; Rosenberger et al., 2002).

In order to investigate the effect of operating variables on treatment of MSG wastewater, a laboratory scale study was conducted. Undoubtedly, this work would be very significant to clean production of the MSG Industry, to efficient treatment and safe discharge of MSG wastewater ${ }^{[13,14,}$ 15].

\section{MATERIAL AND METHODS}

\section{Experimental set-up}

A schematic diagram of the experimental set up is shown in Figure 1. Anaerobic pre-treatment (Upflow Anaerobic Sludge Blanket, UASB) followed by aerobic post-treatment (Membrane Bioreactor, MBR) was chosen for the present study.

An UASB reactor consisted of a perspex column made by joining two sections of different lengths of $90 \mathrm{~mm}$ internal diameter measuring to a height of $1,200 \mathrm{~mm}$ with a constant temperature plexiglass casing. Over this, an upper section of $150 \mathrm{~mm}$ diameter and $300 \mathrm{~mm}$ length was mounted to prevent carry over of suspended particles into the effluent and also to serve as a gas holder, named three-phase separator. The working volume of the reactor was worked out to be $9.5 \mathrm{~L}$. The feed pumping system consisted of two peristaltic pumps operated alternatively at specified time interval by means of a digital timer system to ensure 24 hours continuous operation. The UASB reactor was operated with a temperature of $38 \pm 1^{\circ} \mathrm{C}$. The UASB effluent was connected to the MBR inlet.

The A/OMBR unit consists of two perspex columns with a diameter of $90 \mathrm{~mm}$ and a height of $1,500 \mathrm{~mm}$. The membrane module was a microfiltration hollow fiber made of Polyvinylidene fluoride (PVDF). The membrane module was fully submerged into the medium in the column. The bottom part incorporated inlets for the influent and air, the top part incorporated outlets for the effluent and air. Bioreactor was operated at room temperature $\left(20-25^{\circ} \mathrm{C}\right)$, controlled by a programmable logic controller (PLC). Liquid level probes (including a high level detector and a low one) were placed in the reactor. Pumps and automated valves were interconnected via the PLC with the liquid level probes. The total volume of the reactor is 11.81 and the hydraulic residence time (HRT) was $24 \mathrm{~h}$. The valves for sludge discharge and the air inlet were set at the bottom of the reactor.

\section{Industrial wastewater and seed}

The industrial wastewater (MSG) was supplied by a MSG factory in North China, and the characteristics of MSG wastewater are presented in Table 1. The seeding material required for the start-up of the reactor was procured from a municipal wastewater plant.

TABLE I. CHARACTERISTICS OF MSG WASTEWATER

\begin{tabular}{|c|c|c|}
\hline $\begin{array}{c}\text { Paramete } \\
\mathbf{r}\end{array}$ & Unit & Value \\
\hline $\mathrm{COD}_{\mathrm{cr}}$ & $\mathrm{mg} \cdot \mathbf{l}^{-1}$ & $5405-17000$ \\
\hline $\mathrm{BOD}_{5}$ & $\mathrm{mg} \cdot 1^{-1}$ & $3000-9000$ \\
\hline $\mathrm{Cl}^{-}$ & $\mathrm{mg} \cdot 1^{-1}$ & $8000-10000$ \\
\hline $\mathrm{SO}_{4}{ }^{2-}$ & $\mathrm{mg} \cdot 1^{-1}$ & $3500-6000$ \\
\hline $\mathrm{pH}$ & - & $3.0-3.2$ \\
\hline $\mathrm{NH}_{3}-\mathrm{N}$ & $\mathrm{mg} \bullet{ }^{-1}$ & $800-2100$ \\
\hline
\end{tabular}




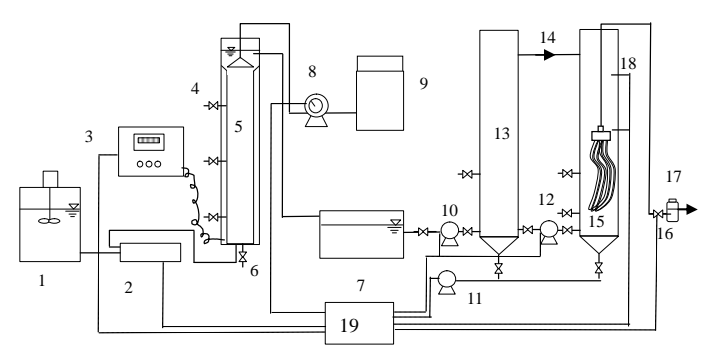

1 Feed tank; 2 Feed pump; 3 Automatic temperature controller;

4 Sampling valve; 5 UASB Reactor column; 6 Discharge valve;

7 Storage tank; 8 Wet gas meter; 9 Gasholder ; 10 Pressure

pump;11 air compressor; 12 return pump; 13 anaerobic reactor;

14 outlet; 15 MBR; 16 water valve; 17 constant bit bottle; 18

level control probe; 19 PLC

Figure 1. Schematic diagram of the UASB-Reactor and MBR-System

\section{Chemical analyses}

The Chemical Oxygen Demand (COD), Volatile Solids (VS), ammonia $\left(\mathrm{NH}_{3}-\mathrm{N}\right)$, pH, and Volatile Suspended Solids (VSS) of samples are analyzed as per the procedure given in the Standard Methods (APHA,2005) ${ }^{[16]}$. Volatile fatty acids (VFA) determination was performed by HPLC, with a Jasco unit.

\section{RESULTS AND DISCUSSION}

\section{UASB stage}

After 2 months cultivate, UASB reactor deal with a high strength MSG wastewater successful implementation of the sludge particles and maintain the reactor higher sludge concentration, and ensuring the stable operation of high load. The operating experiment was divided into five phases, the operating parameters of each operating phase were showed in Table 2 . Weekly analysis of the sludge collected from the UASB reactor indicate that the concentration of the sludge ranged from7.49 $\mathrm{g} \mathrm{VSS} \cdot 1^{-1}(\mathrm{VSS} / \mathrm{TSS}=0.22)$ to $13.27 \mathrm{~g} \mathrm{VSS}^{-1} 1^{-1}(\mathrm{VSS} / \mathrm{TSS}=0.47)$, with an average value of $11 \mathrm{~g} \mathrm{VSS} \cdot 1^{-1}$.

The characteristics of raw wastewater and UASB-effluent are recorded in Table II and illustrated graphically in Figs 2-6. 
EACH OPERATING PHASE

\begin{tabular}{|c|c|c|c|c|c|c|c|c|}
\hline $\begin{array}{l}\text { Pha } \\
\text { ses }\end{array}$ & $\begin{array}{c}\text { Ti } \\
\text { me } \\
\text { of } \\
\text { eac } \\
\text { h } \\
\text { pha } \\
\text { se } \\
\text { / d }\end{array}$ & $\begin{array}{c}\text { Influ } \\
\text { ent } \\
\text { COD } \\
/ \\
\text { mg.l- }\end{array}$ & \begin{tabular}{|c} 
efflu \\
ent \\
CO \\
D \\
$/$ \\
mg. ${ }^{-}$
\end{tabular} & $\begin{array}{c}\text { Remo } \\
\text { val } \\
\text { of } \\
\text { COD } \\
/ \%\end{array}$ & $\begin{array}{c}\text { efflue } \\
\text { nt } \\
\mathrm{NH}_{3^{-}} \\
\mathrm{N} \\
/ \\
\mathbf{m g} \cdot \mathbf{l}^{-1}\end{array}$ & $\begin{array}{c}\text { HR } \\
\text { T } \\
/ \mathbf{d}\end{array}$ & $\begin{array}{c}\text { Ga } \\
\text { S } \\
\text { yiel } \\
\text { d } \\
\text { Rat } \\
\text { io } \\
/ \\
\mathbf{l} \cdot \mathbf{k} \\
\mathbf{g}^{-1} \\
\text { CO } \\
\text { D }\end{array}$ & $\begin{array}{c}\mathbf{O L} \\
\mathbf{R} \\
/ \mathbf{k g} \\
\mathbf{C O} \\
\mathbf{D} \\
\cdot \mathbf{m}^{-} \\
3 \cdot \mathbf{d} \\
-\mathbf{1}\end{array}$ \\
\hline 1 & 14 & $\begin{array}{c}1198 \\
6\end{array}$ & $\begin{array}{c}1019 \\
6\end{array}$ & 16.02 & - & $\begin{array}{l}1.9 \\
01\end{array}$ & $\begin{array}{c}0.4 \\
74\end{array}$ & $\begin{array}{c}5.8 \\
2\end{array}$ \\
\hline 2 & 8 & 6000 & 4251 & 32.43 & 953 & $\begin{array}{l}1.9 \\
67 \\
\end{array}$ & $\begin{array}{c}0.6 \\
15 \\
\end{array}$ & $\begin{array}{c}3.0 \\
2\end{array}$ \\
\hline 3 & 9 & 7934 & 3226 & 59.36 & 1188 & $\begin{array}{l}2.1 \\
47\end{array}$ & $\begin{array}{c}0.5 \\
09\end{array}$ & $\begin{array}{c}3.2 \\
9\end{array}$ \\
\hline 4 & 16 & $\begin{array}{c}1414 \\
9\end{array}$ & 3928 & 69.83 & 1777 & $\begin{array}{l}1.9 \\
10\end{array}$ & \begin{tabular}{|c|}
0.4 \\
61 \\
\end{tabular} & $\begin{array}{c}6.0 \\
8\end{array}$ \\
\hline 5 & 13 & $\begin{array}{c}1466 \\
7\end{array}$ & 5060 & 65.44 & 2338 & $\begin{array}{l}1.7 \\
31 \\
\end{array}$ & $\begin{array}{c}0.5 \\
58 \\
\end{array}$ & $\begin{array}{c}8.8 \\
3\end{array}$ \\
\hline
\end{tabular}

The quality of the reactor effluent confirms the effectiveness of the UASB as a pre-treatment technology for MSG wastewater. Total COD removal values were 48.6\%. The corresponding residual value was $5332 \mathrm{mgO}_{2} \bullet 1^{-1}$ in average. The biogas production rate in this experiment ranged between $0.461 \mathrm{l} \cdot \mathrm{kg}^{-1} \mathrm{COD}$ and $0.615 \mathrm{l} \cdot \mathrm{kg}^{-1} \mathrm{COD}$.

\section{a. Effect of influent COD in UASB}

Initially the influent COD was kept within the range $10476-13333 \mathrm{mg} \cdot \mathrm{l}^{-1}$ (the top concentration of influent COD at the end of start-up phase), but the results showed that the influent COD was too high that methanogenic bacteria in the reactor could not fit it. This caused acid accumulation, $\mathrm{pH}$ dropped to 6.5, and gas yield was declined. Thus the influent COD was decreased to 5405-7372 $\mathrm{mg}$ $-1^{-1}$ in Phase 2. It was observed from Figure 2 that the effluent COD was decreased, and the COD removal percentage was increased from 16 to $70 \%$ with operation time in Phase 2 . An efficiency of $76.0 \%$ was obtained at a maximum OLR of $8.83 \mathrm{~kg} \mathrm{COD} \cdot \mathrm{m}^{-3} \cdot \mathrm{d}^{-1}$.

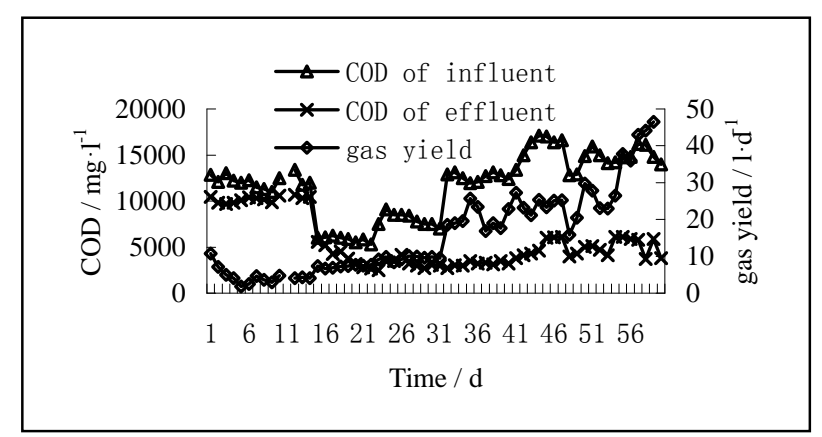

Figure 2. Variation of COD and gas yield in UASB

\section{b. OLR and COD removal rate}

By the OLR and the COD removal rate curve (Figure 3), the OLR and removal rate showed approximate linear relationship in low-load operation phase, COD removal rate was increased with 
the OLR increasing. With the sludge acclimation, the COD removal rate increased rapidly. And when to high-load stage, COD removal rate gradually stabilized and declined slightly.

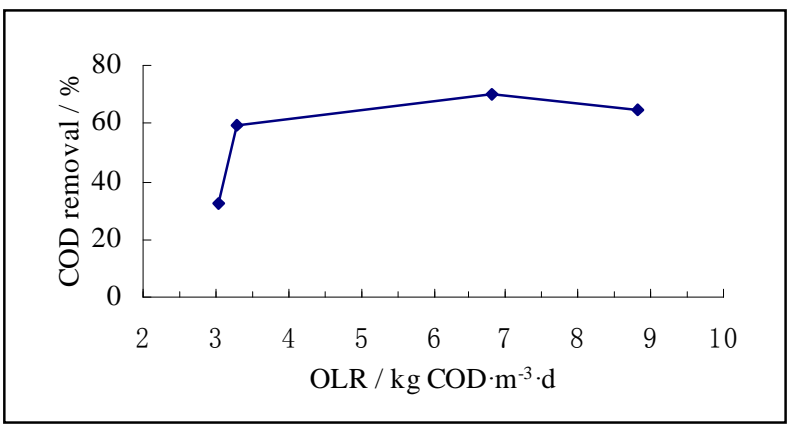

Figure 3. Variation of COD removal with OLR in UASB

\section{c. Biogas Recovery in USAB}

The variation of biogas with time of operation for each phase was plotted in Figure 2. Because of methanogenic bacteria failed to adapt to the influent COD concentration at Phase 1, gas yield was declined from $101 \cdot \mathrm{d}^{-1}$ to $2 \mathrm{l} \cdot \mathrm{d}^{-1}$. However, after more than 10 days of operation, the microorganisms adapt quickly to the influent concentration, gas production has gradually picked up. It was observed that the biogas yield was increased with increase of OLR. The maximum biogas yield was observed to be $46.51 \cdot \mathrm{d}^{-1}$. The composition of the biogas was analyzed using a high performance gas chromatograph and the consistent methane percentage was found to be $53-62 \%$. Figure 4 showed that the volumetric gas yield and OLR was positive correlation.

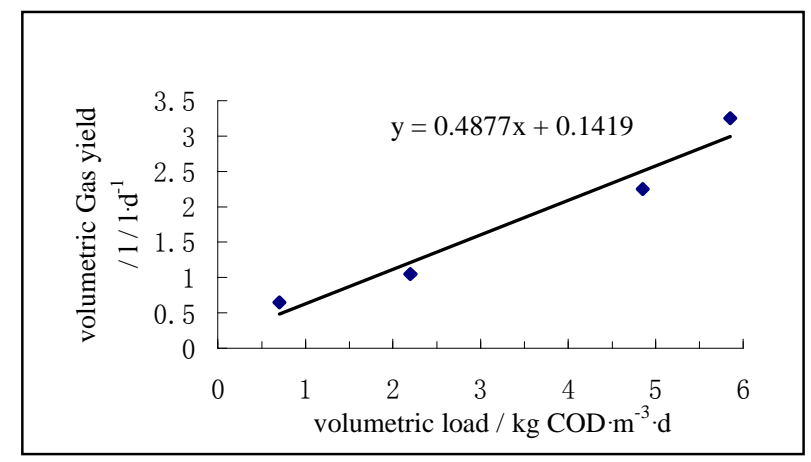

Figure 4. Variation of gas yield with OLR in UASB

\section{d. VFA and pH in UASB}

The variation of the effluent VFA with the $\mathrm{pH}$ for each phase was plotted in Figure 5. The results showed that: at the phase 1, too higher influent COD caused VFA accumulation in the reactor, effluent $\mathrm{pH}$ declined significantly too; because of the buffer capacity for $\mathrm{pH}$ in the reactor was low at the initial stage. With the buffer capacity increasing, although the fluctuation of influent VFA was violently, $\mathrm{pH}$ and VFA of effluent were stable, even influent $\mathrm{pH}$ declined to 3.2, at the end of Phase 5. This means the UASB with good buffer capacity for $\mathrm{pH}$ could ensure the acidogenic bacteria and methanogenic bacteria balance and Methanogens high activity, and could deal with the acidic organic wastewater $(\mathrm{pH}<3.5)$ without adjusting $\mathrm{pH}$ by dozing alkali salts. 


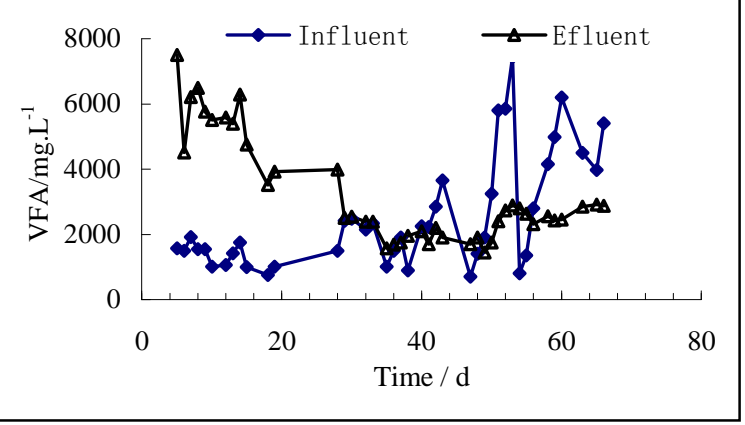

Figure 5. Variation of VFA with time in UASB

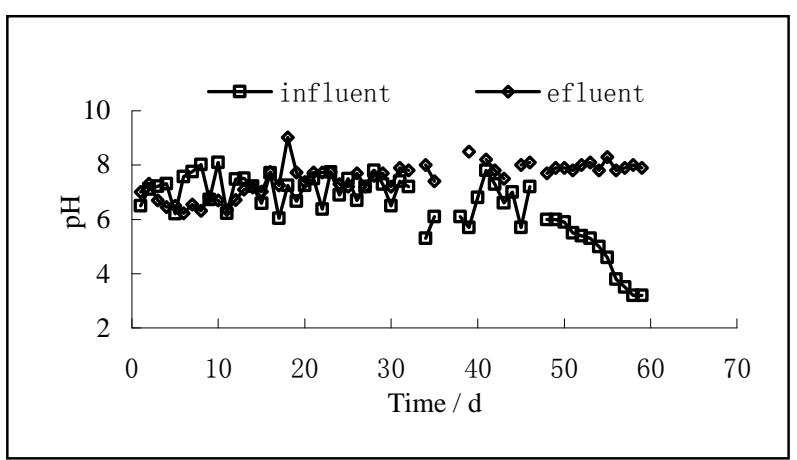

Figure 6. Variation of $\mathrm{pH}$ with time in UASB

\section{MBR stage}

The results recorded in Table II indicate that the quality of the UASB-effluent narrowly complied with the Standards regulating discharge of wastewaters into the sewerage network. Therefore, proper post-treatment is required. MBR was used for that purpose. The results obtained indicate very good carbonaceous matter and ammonia elimination as reacted in the removal of COD (97\%), and $\mathrm{NH}_{3}-\mathrm{N}$ (96\%). Residual COD values varied from $62 \mathrm{mg} \mathbf{l}^{-1}$ to $242 \mathrm{mg} \cdot \mathbf{l}^{-1}$, with an average value of 101 $\mathrm{mg} \cdot 1^{-1}$. Corresponding $\mathrm{NH}_{3}-\mathrm{N}$ values ranged from $21 \mathrm{mg} \cdot 1^{-1}$ to $96 \mathrm{mg} \cdot \bullet^{-1}$, with an average value of 51 $\mathrm{mg} \cdot \bullet^{-1}$, respectively.

TABLE III. EFFICIENCY OF THE MBR REACTOR FOR THE TREATMENT OF MSG WASTEWATER OF EACH OPERATING PHASE

\begin{tabular}{|c|c|c|c|c|c|c|c|}
\hline $\begin{array}{l}\text { Pha } \\
\text { ses }\end{array}$ & $\begin{array}{c}\text { Ti } \\
\text { me } \\
\text { of } \\
\text { eac } \\
\text { h } \\
\text { pha } \\
\text { se } \\
\text { / d } \\
\end{array}$ & $\begin{array}{c}\text { Influ } \\
\text { ent } \\
\text { COD } \\
/ \\
\mathrm{mg} \cdot \mathrm{I}^{-}\end{array}$ & $\begin{array}{c}\text { Efflu } \\
\text { ent } \\
\text { COD } \\
/ \\
\text { mg. } \\
\mathbf{l}^{-}\end{array}$ & $\begin{array}{c}\text { Remo } \\
\text { val } \\
\text { of } \\
\text { COD } \\
/ \%\end{array}$ & $\begin{array}{c}\begin{array}{c}\text { Influ } \\
\text { ent }\end{array} \\
\mathrm{NH}_{3}- \\
\mathrm{N} \\
/ \\
\mathbf{m g} \cdot \mathrm{I}^{-}\end{array}$ & \begin{tabular}{|c} 
Efflue \\
nt \\
$\mathrm{NH}_{3}-\mathrm{N}$ \\
$\mathbf{m g} \cdot \mathbf{l}$ \\
$\mathbf{1}$
\end{tabular} & \begin{tabular}{|c|} 
RemopH \\
val \\
of \\
$\mathrm{NH}_{3^{-}}$ \\
$\mathrm{N}$ \\
$/ \%$
\end{tabular} \\
\hline 1 & 14 & - & - & - & - & - & - \\
\hline 2 & 8 & 4251 & 143 & 96.6 & 953 & 27 & 97.26 .7 \\
\hline 3 & 9 & 3226 & 90 & 97.2 & 1188 & 33 & \begin{tabular}{l|l|}
97.2 & 7.7 \\
\end{tabular} \\
\hline 4 & 16 & 3928 & 90 & 97.7 & 1931 & 74 & 96.27 .5 \\
\hline $5^{*}$ & 13 & 2552 & 84 & 96.7 & 1392 & 68 & \begin{tabular}{|l|l|}
95.1 & 7.9 \\
\end{tabular} \\
\hline
\end{tabular}

*In the phase 5, the effluent was returned back to MBR with returned ratio of 1:1

\section{a. Effect of influent COD in MBR}

COD removal in MBR was shown in Figure 7, influent COD fluctuation range of $2552 \sim 4251$ $\mathrm{mg} \cdot \mathrm{l}^{-1}$, effluent COD was under $150 \mathrm{mg} \cdot \mathrm{l}^{-1}$ stablely and removal rate of COD up to about $97 \%$. 
When the COD value is transferred to $6100 \mathrm{mg} \bullet 1^{-1}$, COD values could meet the $170 \mathrm{mg} \bullet{ }^{-1}$, COD that the system has strong resistance to impact load.

\section{Ammonia nitrogen removal}

Ammonia nitrogen removal in MBR was shown in Figure 8, ammonia nitrogen removal rate in the each phases of the experiment reached above $95 \%$, but as the ammonia nitrogen of influent above $2300 \mathrm{mg} \mathrm{l}^{-1}$, the ammonia nitrogen of effluent increased to $96 \mathrm{mg} \cdot \mathrm{l}^{-1}$. In the phase 5 , the effluent was returned back to MBR with returned ratio of $1: 1$, and the ammonia nitrogen of effluent decreased back to $48 \mathrm{mg} \mathrm{l}^{-1}$. In the process of ammonia removal, ammonia oxidation per gram of nitrate need to consume $7.14 \mathrm{~g}$ alkalinity ${ }^{[17]}$. Raw water alkalinity in $1500 \sim 2400 \mathrm{mg} \cdot \mathrm{l}^{-1}$ between the fluctuations, can not fully provide the necessary alkalinity of ammonia removal, so the addition of $\mathrm{Na}_{2} \mathrm{CO}_{3}$ was required to the system to adjust the system $\mathrm{pH}$ value and alkalinity.

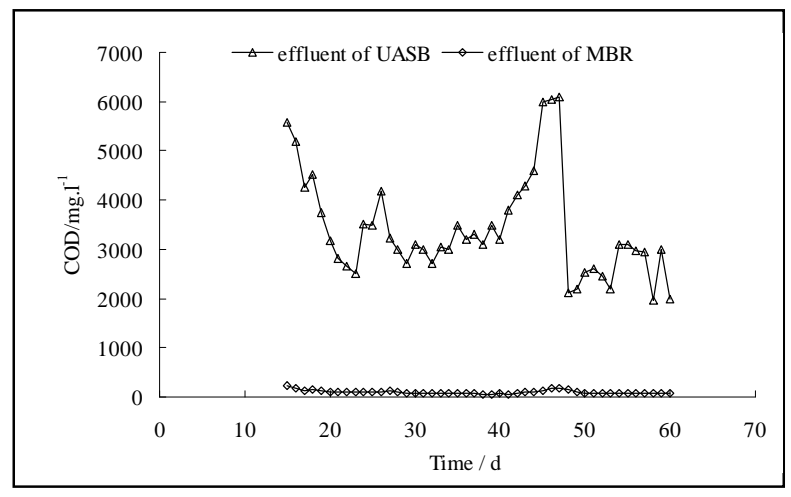

Figure 7. COD removal effect by MBR

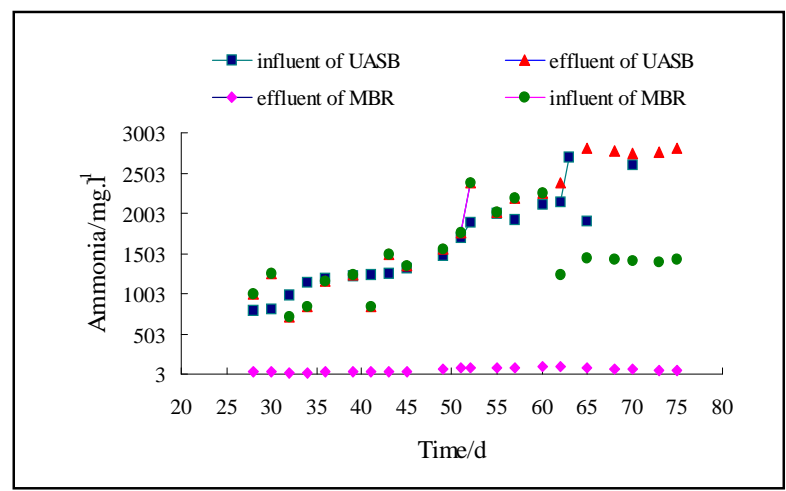

Figure 8. Ammonia removal effect by MBR

\section{c. pH value change}

The $\mathrm{pH}$ value changes within the system was shown in Figure 9. The nitrification could cause the accumulation of $\mathrm{H}^{+}$and the decreasing of $\mathrm{pH}$. Nitrifying bacteria had the highest activity under the $\mathrm{pH}$ value of 7.0 to 8.1 . Nitrifying bacteria sensitive to changes in $\mathrm{pH}$ value in the biological treatment system, the denitrification optimum $\mathrm{pH}$ range of 7.0 to 7.5 , if the $\mathrm{pH}$ value dropped to 5.0 to 5.5, the denitrification reaction almost stopped. With adding soda ash, $\mathrm{pH}$ remained 7.5 , so the nitration reaction was complished well. 


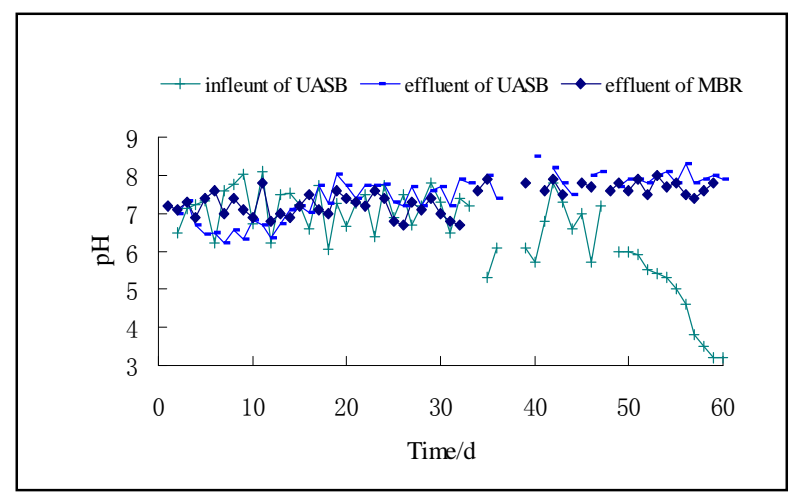

Figure 9. Variation of $\mathrm{pH}$ in $\mathrm{MBR}$

\section{CONCLUSION}

- The treatment of high COD and high ammonia monosodium glutamate wastewater by A/O MBR is studied. UASB reactor under high concentrations of MSG wastewater treatment, there is a higher gas production rate, at $3.02-8.83 \mathrm{~kg} C O D / \mathrm{m}^{3} \cdot \mathrm{d}$ volume load, the average gas production rate of $0.599 \mathrm{~m}^{3} / \mathrm{kg}$ COD, High Load under the gas production rate and COD load volume was positively related to each other.

- In the stable operating phases, as influent COD in range of $11878-16922 \mathrm{mg}^{-1}{ }^{-1}$, COD removal rate of effluent was in range of $57.00-79.63 \%$, average COD concentration of effluent was $5446 \mathrm{mg} \cdot \mathrm{l}^{-1}$; the average gas production rate was $0.5085 \mathrm{~m}^{3} \cdot \mathrm{kg}^{-1} \mathrm{COD}$, gas production rate and the organic load was positive correlation.

- UASB with high buffering capacity of the stability in case of high load of acid-base environment, could deal with the acidic organic wastewater $(\mathrm{pH}<3.5)$ without adjusting $\mathrm{pH}$ by dozing alkali salts.

- The removal of COD by MBR can reach $96 \%$ even to $98 \%$ and the removal of ammonia is 95\% - $99 \%$. The experimental results show that A/O MBR has a good ability of preventing fluctuation of load and can remove COD and ammonia effectively.

\section{ACKNOWLEDGMENT}

THE AUTHORS WISH TO ACKNOWLEDGE THE ENVIRONMENTAL EXPERIMENT CENTRAL LAB, HeBEI INSTITUTE OF Architecture and Engineering, Zhang Jiakou, China, for their support in carrying out the experimental work.

\section{REFERENCES}

[1] Liqun Jiang, Haiyan Pei, Wenrong Hu, Yan Ji, Lin Han, Guixia Ma, The feasibility of using complex wastewater from a monosodium glutamate factory to cultivate Spirulina subsalsa and accumulate biochemical composition, Bioresource Technology, 2015, 180(3): 304-310

[2] Liu J X, Yue Q Y, Gao B Y, Ma Z H, Zhang P D. Microbial treatment of the monosodium glutamate wastewater by Lipomyces starkeyi to produce microbial lipid. Bioresour Technol. 2012,106:69-73.

[3] LIU Rui, ZHOU Qixing, ZHANG Lanying, GUO Hao. Toxic effects of wastewater from various phases of monosodium glutamate production on seed germination and root elongation of crops. Chinese Journal of Applied Ecology, 2006, 17(7):1286-1290.

[4] Fang S, Li X-H. A study on treatment of MG wastewater with process of adsorption and twostage SBR.J Zhejiang Univ (Agric Life Sci ), 2001, 27(2), pp. 210-214 ( in Chinese).

[5] Yang Y, Sun Z-S. Countermeasures for monsodium glutamate control China Biogas, 2004, 22(1): 18-21 (in Chinese).

[6] Zhou Q-X, Kong F-X, Zhu L. Ecotoxicology. Beijing: Science Press. 2004. (in Chinese). 
[7] Revanuru Subramanyam, I.M. Mishra. Treatment of catechol bearing wastewater in an upflow anaerobic sludge blanket (UASB) reactor: Sludge characteristics. Bioresource Technology, 2008, 18 (99) : 8917-8925.

[8] N. Musee, M.A. Trerise, L. Lorenzen. Post-treatment of Distillery Wastewater after UASB using Aerobic Techniques. south african journal of enology and viticulture., 2007, 28(1):50-55.

[9] Kaan Yetilmezsoy, Zehra Sapci-Zengin. Stochastic modeling applications for the prediction of COD removal efficiency of UASB reactors treating diluted real cotton textile wastewater. Stochastic environmental research and risk assessment, 2009, 23 : 13-26.

[10] Matsumoto, A. and Noike, T. Effects of substrate composition and loading rate on methanogenic process in anaerobic fluidized bed systems. Wat. Sci. Tech., 1991, 23(7-9): $1311-1317$.

[11] Chen, C.Y., Li, C.T. and Shieh, W.K. Anaerobic fluidized bed pretreatment of hog wastewater. J. Env. Eng. Div., ASCE, 1997, 23(4): 389-394.

[12] Tseng, S.K. and Lin, M.R. Treatment of monosodium glutamate fermentation wastewater with anaerobic biological fluidized bed process. Wat. Sci. Tech., 1990, 22(9): 149-155.

[13] Sven Lyko. Long-term monitoring of a full-scale municipal membrane bioreactorCharacterisation of foulants and operational performance[J]. Membrane Science, 2008,(12):78-87.

[14] Yang Wenbo, Nazim Cicek, John I lg. State-of-the-art of membrane bioreactors: Worldwide research and commercial applications in north America [J].Journal of Membrane Science, 2006, 270(1-2): 201-211.

[15] Heppner, B., Zellner, G. and Diekmann, H. Start-up operation of a propionate-degrading fluidized bed reactor. Appl. Microbiol.Biotechnol., 1992, 36: 810-816.

[16] Hickey, R.F., Wu, W.M., Veiga, M.C. and Jones, R. Start-up, operation, monitoring and control of high-rate anaerobic treatment systems. Wat. Sci. Tech., 1991, 24(8): 207-255.

[17] Sreekrishnan, T.R., Ramachandran, K.B. and Ghosh, P. Effect of operating variables on biofilm formation and performance of an anaerobic fluidized bed reactor. Biotech. Bioeng., 1991, 37: 557-566.

[18] APHA-AWWA-WPCF. Standard Methods for the Examination of Water and Wastewater, 21st Edition, 2005.

[19] Ruiz G, Jeison D, Rubilar O,et al. Nitrification-denitrification via nitrite accumulation for nitrogen removal from wastewaters[J]. Bioresource Technology,2006,97:330-335. 